\section{Sleep disturbances and daytime fatigue: data from the Brazilian National Health Survey, 2013}

\author{
Distúrbios do sono e fadiga durante o dia: dados \\ da Pesquisa Nacional de Saúde, 2013
}

\section{Trastornos del sueño y fatiga diurna: datos de la Encuesta Nacional de Salud, 2013}

\author{
Andrea Wendt 1 \\ Caroline Santos Costa 1 \\ Adriana Kramer Fiala Machado 1 \\ Francine Santos Costa 1 \\ Rosália Garcia Neves 1 \\ Thaynã Ramos Flores 1 \\ Iná Santos 1 \\ Fernando César Wehrmeister 1
}

doi: 10.1590/0102-311X00086918

\begin{abstract}
This study aims to describe the prevalence of sleep disturbances and daytime fatigue and their association with socio-demographic and behavioral factors. Data from the Brazilian National Health Survey conducted in 2013 with 60,202 adults ( $\geq 18$ years old) were used. The outcomes evaluated were selfreported sleep disturbances and daytime fatigue in the last two weeks. Sleep disturbance was defined as the presence of difficulty to fall asleep, frequently waking up during the night or sleeping more than usual; daytime fatigue was defined as the presence of not feeling rested and motivated during the day, feeling tired and lacking energy. Sociodemographic, lifestyle and chronic health aspects were explored as exposures for both outcomes. Prevalence of sleep disturbances and daytime fatigue were 14.9\% (14.4-15.4) and 11.9\% (11.4-12.3), respectively. Both outcomes were more common in women, older people, people with no formal education, smokers and among physically inactive individuals. The association with education was inverse (the highest the level of education the lower the prevalence ratio - PR - of sleep disturbances and daytime fatigue; adjusted $p$-value for trend $<0.001)$. Prevalence of sleep disturbances combined with daytime fatigue was 6.7\% (6.4-7.1) and was about 6 times higher among those with three or more chronic health disturbances $(P R=6.2 ; 95 \% C I: 5.3-7.2)$. Strategies to decrease the prevalence of sleep disturbances and daytime fatigue should be encouraged and focused on chronically ill individuals that share other modifiable risk factors.
\end{abstract}

Sleep Disorders; Fatigue; Cross-sectional Studies; Health Surveys

\author{
Correspondence \\ A. Wendt \\ Universidade Federal de Pelotas. \\ Rua Marechal Deodoro 1160, 3o andar, Pelotas, RS 96020-220 \\ Brasil. \\ andreatwendt@gmail.com
}

1 Universidade Federal de Pelotas, Pelotas, Brasil. 


\section{Introduction}

Sleep is a physiological human need, essential for organic basic functions, such as hormonal secretion, metabolism, tissues restoration and immunological system 1,2,3. Insufficient sleep duration, poor sleep quality and sleep disorders (e.g., insomnia and sleep apnea) are related to higher risk of all-cause mortality 4 , impaired mental health 5,6 , obesity 5,7 , learning and memory problems 8,9 , and chronic diseases $5,6,10$. Sleep disturbances are also associated to higher risks of work-related accidents and car crashes due to daytime sleepiness as a result of poor sleep nights 11.

Population-based studies have shown that several sleep disturbances affect people worldwide. In the United States (2009), a study found that one third of participants presented inadequate sleep duration (considering seven hours as adequate) 12. Self-reported daytime sleepiness affected $12 \%$ of adults in a Korean sample in 2015 13. In a study performed in Finland (2014), 16\% of the sample presented difficulty in initiating sleep 14. A large study carried out in eight countries of Africa and Asia found a point prevalence (last 30 days) of $16.6 \%$ nocturnal sleep disturbances, defined as difficulty in falling asleep, frequently waking up during the night, waking up too early in the morning, and not feeling rested and refreshed during the day ${ }^{15}$. In Colombia, sleep complaints affect $59.9 \%$ of the population 16. A study conducted in 2012 showed that $21 \%$ of Brazilian workers presented poor sleep quality, with sleep disturbances being more frequent among physically inactive individuals, in those with higher alcohol consumption levels, and with diabetes mellitus or arterial hypertension 17.

In Brazil, multiple studies measuring sleep disturbances were performed, namely, the Epidemiologic Sleep Study in São Paulo 18, the Bambui Health and Ageing Study, including older adults 19, the ELSA Study with workers 20 and the Baependi Heart Study with a rural sample 21. A monitoring study in São Paulo found an increased difficulty in initiating sleep from $13.9 \%$ in 1987 to $25 \%$ in 200718 . The study also identified an increased difficulty in maintaining sleep from $15.8 \%$ in 1987 to $36.5 \%$ in 200718 . The study with older adults found a 38.9\% prevalence of insomnia 19 while the prevalence for sleep problems was $33.8 \%$ in the study with workers 20 . The study in a rural area found $34.9 \%$ prevalence of poor sleep quality 21. Although these studies have high methodological quality and are crucial to the research area, Brazil is a huge country with many differences across its regions. Thus, sleep information with a representative sample of the country is still necessary. One study with a Brazilian sample evaluated sleep disturbances and found that $63 \%$ of the participants presented at least one sleep complaint. However, this study did not evaluate behavioral risk factors nor health conditions 22 .

Although sleep is a relevant public health problem affecting several aspects of human health and performance, there are few population-based studies considering a representative sample from Brazil which evaluate sociodemographic, behavioral and chronic health conditions. Therefore, this study aimed to describe the prevalence of sleep disturbances and daytime fatigue and to evaluate the association with socio-demographic and behavioral factors and with chronic morbidity in Brazil, using data from the 2013 Brazilian National Health Survey (NHS).

\section{Methods}

The Brazilian Ministry of Health in partnership with the Brazilian Institute of Geography and Statistics (IBGE) carried out the NHS in 2013. The aim of the NHS is to periodically (every five years) monitor Brazilian health outcomes.

The NHS sampling process was carried out in three stages. First, a census sector or a set of census sectors (depending on the number of permanent private households) was randomly selected. The second stage comprised the random selection of households at random and the third stage was the inclusion of a single household member aged 18 or more years-old. The household member was selected using a simple random draw. Sample size was calculated based on prevalence of indicators measured in NHS for each population group and Federation Unit. The calculation also considered a sampling plan. The NHS loss in the 18 years or more sample was $25.9 \%$. Detailed information about the sampling process can be found elsewhere 23 .

The information used in this study was gathered in interviews conducted by trained fieldworkers employing a structured and pretested questionnaire. Sleep disturbances and daytime fatigue were 
assessed via the answer given to the following questions: "In the last two weeks, how often have you had difficulty in falling asleep, woken up frequently during the night or slept more than usual?" and "In the last two weeks, how often have you had problems because you did not feel rested and motivated during the day, feeling tired and lacking energy?”. The answer options were: none; up to seven days; more than seven days; almost every day. For analysis purposes, the variables were dichotomized and those who answered more than seven days or almost every day for each question were classified as having sleep disturbances or daytime fatigue.

The following independent variables were evaluated: sex (male, female); age (18-29, 30-39, 40-49, 50-59, and 60 years or more); skin color (white, brown, Asian/native South American or black); education (none, incomplete primary level, complete primary level, secondary level, and higher education); living with a partner (yes, no); leisure-time physical activity (at least 150 minutes per week: yes, no); currently a smoker (yes, no); alcohol intake (at least once a week, less than once a week, regardless of doses) and wealth index. White skin color was defined as reference in the analyses due to its higher weighed percentage when compared to other skin colors. The wealth index was built using principal component analyses based on ownership of the following assets: car, motorcycle, computer, microwave, mobile phone, landline phone, washing machine, DVD player, refrigerator, television, bathroom with shower, and number of bedrooms. In addition, a health problem score with the following conditions was built: obesity (body mass index $-\mathrm{BMI} \geq 30 \mathrm{~kg} / \mathrm{m}^{2}$ ), depression, arterial hypertension, diabetes mellitus, lung disease, asthma or bronchitis, rheumatic disorders, cancer, renal insufficiency, high cholesterol, heart disease, stroke, low back disorders, and work-related musculoskeletal disorders. Weight and height were measured with a portable electronic scale and portable anthropometer. All conditions except obesity were self-reported using the following question: "Has any doctor ever diagnosed you with [...]?”. The chronic health problem score was categorized in 0, 1, 2 and 3 or more conditions.

A descriptive analysis of the sample and of the distribution of the outcomes was performed according to the independent variables. Prevalence and 95\% confidence intervals (95\%CI) were presented for the whole country and separately for each Brazilian Federation Unit. Federation Units with sleep problem or daytime fatigue prevalence above the higher $95 \%$ confidence limit of the whole country prevalence were classified as presenting high prevalence and those with prevalence below the lower 95\% confidence limit of the whole country prevalence were classified as presenting low sleep disturbances or daytime fatigue prevalence. A hierarchical analysis was performed to verify the association between sleep disturbances and daytime fatigue with socio-demographic, behavioral and morbidity variables. Prevalence ratios (PR) with 95\%CI were calculated by Poisson regression with robust variance. A three-level model was considered in this analysis: (1) sex, age and skin color; (2) education, wealth index and living with a partner; and (3) leisure-time physical activity, smoking and alcohol intake. All variables associated $(\mathrm{p}<0.05)$ with the outcome in each level were maintained for adjustment of the subsequent levels. To describe sleep disturbances and daytime fatigue according to the health problem score, a variable with four mutually excluding categories (none/only sleep disturbances/only daytime fatigue/both) was created. Significance level for final associations was $\mathrm{p}<0.05$. The analyses were conducted in the software Stata 12.1 statistical package (https://www.stata.com). All analyses were conducted considering the clustering nature of the data. Because the probability of participating in the individual interview varied according to the family size, the sample was standardized before the analyses 23 .

The NHS was submitted to the Brazilian Research and Ethics Commission and was approved under protocol number 10853812.7.0000.0008. All participants signed an Informed Consent Form ensuring confidentiality of individual data. 


\section{Results}

The sample comprised 60,202 individuals. Table 1 shows that sleep disturbances were found in $14.9 \%$ (14.4-15.4) of the sample and the prevalence was higher in women, older individuals, people with no formal education, lower socioeconomic position, physically inactive, smokers, and with lower alcohol consumption. Around 12\% (11.9\%; 11.4-12.3) of the individuals presented daytime fatigue with higher prevalence found in women, among those between 40 and 59 years of age, less educated (none or incomplete primary school level), physically inactive, smokers, and with lower alcohol consumption and higher health problem score. Sleep problem and daytime fatigue increased with the increase in number of chronic health conditions (Table 1). The original variables to sleep disturbances and daytime fatigue have four answer options. The occurrence of sleep disturbances almost every day, more than 7 days, up to 7 days and never in the last 15 days was reported in $9.4 \%, 5.5 \%, 14 \%$ and $71.1 \%$ of the sample, respectively. The frequency of daytime fatigue almost every day, more than 7 days, up to 7 days and never in the last 15 days was $6.6 \%, 5.3 \%, 18.4 \%$ and $69.7 \%$, respectively.

Table 2 presents crude and adjusted PR between the two outcomes and independent variables. After adjustment, women presented $60 \%$ more sleep disturbances and $75 \%$ more daytime fatigue when compared to men. Individuals aged 50 to 59 years presented higher prevalence of sleep disturbances $(\mathrm{PR}=1.87 ; 95 \% \mathrm{CI}: 1.67-2.08)$ and daytime fatigue $(\mathrm{PR}=1.32 ; 95 \% \mathrm{CI}: 1.17-1.49)$ compared to younger individuals (18-29 years old). The prevalence of both outcomes decreased according to the increase in educational level. Highly-educated individuals presented $27 \%$ and $21 \%$ prevalence of sleep disturbance and daytime fatigue, respectively; thus, lower than the observed in those with no formal education ( $\mathrm{p}$-value for linear trend $<0.001$ for both outcomes). Active individuals presented $12 \%$ and $31 \%$ lower prevalence of sleep disturbances and daytime fatigue, respectively, when compared to inactive individuals. Regarding smoking, current smokers presented higher prevalence of sleep disturbances ( $\mathrm{PR}=1.38$; 95\%CI: 1.26-1.50) and daytime fatigue ( $\mathrm{PR}=1.34 ; 95 \% \mathrm{CI}$ : 1.22-1.48) when compared to non-smokers. The associations found in the crude analysis for wealth index and alcohol did not remain after the adjusted analyses. Individuals with higher number of health problems presented higher frequencies of sleep disturbances and daytime fatigue. The higher the number of chronic health problems the higher the PR for sleep disturbances and daytime fatigue ( $\mathrm{p}$-value for linear trend $<0.001$ for both outcomes).

Figure 1 shows the sleep disturbances and daytime fatigue according to the number of chronic health conditions. The adjusted prevalence of sleep disturbances for none, one, two and three or more chronic health conditions were $8.3 \%, 13.9 \%, 20.4 \%$, and $30.1 \%$, respectively. Regarding daytime fatigue, the adjusted prevalence for none, one, two and three or more chronic health conditions were $6.3 \%, 10.5 \%, 16.7 \%$ and $29.6 \%$, respectively.

Regarding the combination of sleep disturbances and daytime fatigue, 4,036 individuals (6.7\%; 6.4-7.1) in total reported such condition. The simultaneity of sleep disturbances and daytime fatigue prevalence increased as the number of health problems increased. Among those with no health problems, the simultaneity was $3 \%$, compared to $18.4 \%$ among those with three or more conditions ( $\mathrm{p}<$ 0.001 for trend). The adjusted prevalence of combined sleep disturbances and daytime fatigue was about six times higher among individuals with three or more chronic health conditions than among those with none, whom were taken as the reference group (adjusted PR $=6.2$; 95\%CI: 5.3-7.2; $\mathrm{p}<$ 0.001). Furthermore, almost two fifths of those with three or more health problems presented at least one of the outcomes.

Figure 2 shows the distribution of sleep disturbances and daytime fatigue according to the Federation Units. Six Federation Units showed low level to sleep disturbances (Rondônia, Amazonas, Pará, Piauí, Rio de Janeiro and Mato Grosso) and four to daytime fatigue (Amazonas, Pará, Ceará and Rio de Janeiro). Six Federation Units presented high level of sleep disturbance (Roraima, Maranhão, Ceará, Rio Grande do Norte, Pernambuco e Distrito Federal) and seven to daytime fatigue (Roraima, Rio Grande do Norte, Pernambuco, Paraná, Santa Catarina, Goiás and Distrito Federal). 
Table 1

Sample description and distribution of sleep disturbances and daytime fatigue $(N=60,202)$. Sample weights were used for percentages and $95 \%$ confidence interval $(95 \% \mathrm{Cl})$.

\begin{tabular}{|c|c|c|c|c|c|}
\hline Variables & $\begin{array}{c}\text { Sample } \\
\text { n (\%) }\end{array}$ & $\begin{array}{c}\text { Sleep problems } \\
\%(95 \% \mathrm{Cl})\end{array}$ & p-value & $\begin{array}{c}\text { Daytime fatigue } \\
\%(95 \% \mathrm{Cl})\end{array}$ & p-value \\
\hline Sex & & & $<0.001$ & & $<0.001$ \\
\hline Male & $25,920(47.1)$ & $11.2(10.6 ; 11.9)$ & & $8.5(7.9 ; 9.1)$ & \\
\hline Female & $34,282(52.9)$ & $18.2(17.5 ; 18.9)$ & & $14.9(14.3 ; 15.6)$ & \\
\hline Age (years) & & & $<0.001$ * & & $<0.001$ \\
\hline $18-29$ & $14,321(26.0)$ & $10.3(9.5 ; 11.2)$ & & $10.1(9.2 ; 10.8)$ & \\
\hline $30-39$ & $14,269(21.6)$ & $12.5(11.6 ; 13.5)$ & & $12.0(11.1 ; 12.9)$ & \\
\hline $40-49$ & $11,405(18.1)$ & $15.9(14.7 ; 17.0)$ & & $13.2(12.0 ; 14.3)$ & \\
\hline $50-59$ & $9,030(16.2)$ & $19.5(18.1 ; 20.9)$ & & $13.3(12.2 ; 14.5)$ & \\
\hline 60 or more & $11,177(18.1)$ & $19.3(18.1 ; 20.6)$ & & $11.9(10.9 ; 12.9)$ & \\
\hline Skin color ** & & & 0.315 & & 0.690 \\
\hline White & $24,106(47.4)$ & $14.6(14.0 ; 15.5)$ & & $12.0(11.3 ; 12.7)$ & \\
\hline Black & $5,361(9.2)$ & $13.8(12.3 ; 15.2)$ & & $11.3(9.9 ; 12.6)$ & \\
\hline Brown & $29,512(42.0)$ & $15.4(14.6 ; 16.1)$ & & $11.8(11.2 ; 12.5)$ & \\
\hline Asian/Native South American & $950(1.4)$ & $14.5(10.2 ; 18.9)$ & & $13.2(9.7 ; 16.8)$ & \\
\hline Education & & & $<0.001$ & & $<0.001$ \\
\hline None & $9,434(13.9)$ & $19.5(18.0 ; 21.0)$ & & $13.6(12.4 ; 14.8)$ & \\
\hline Incomplete primary level & $14,649(25.7)$ & $17.5(16.4 ; 18.5)$ & & $13.4(12.4 ; 14.5)$ & \\
\hline Complete primary level & $9,215(15.2)$ & $14.2(12.9 ; 15.5)$ & & $11.6(10.4 ; 12.8)$ & \\
\hline Secondary level & $19,149(32.3)$ & $12.1(11.3 ; 12.8)$ & & $10.9(10.1 ; 11.6)$ & \\
\hline Higher education & $7,755(12.9)$ & $13.1(11.7 ; 14.5)$ & & $11.4(9.9 ; 12.9)$ & \\
\hline Wealth index (quintiles) & & & 0.002 & & 0.062 \\
\hline 1st (richer) & $12,066(13.7)$ & $16.3(15.2 ; 17.4)$ & & $11.7(10.7 ; 12.8)$ & \\
\hline $2^{\text {nd }}$ & $12,063(25.3)$ & $15.5(14.4 ; 16.6)$ & & $13.2(12.3 ; 14.2)$ & \\
\hline $3 \mathrm{rd}$ & $11,993(15.5)$ & $15.7(14.6 ; 16.9)$ & & $11.2(10.1 ; 12.3)$ & \\
\hline $4^{\text {th }}$ & $12,040(32.8)$ & $14.7(13.7 ; 15.8)$ & & $10.7(10.0 ; 11.4)$ & \\
\hline 5th (poorer) & $12,040(12.7)$ & $13.4(12.4 ; 14.4)$ & & $11.3(10.0 ; 12.5)$ & \\
\hline Lives with a partner & & & 0.939 & & 0.294 \\
\hline No & $25,680(38.8)$ & $15.0(14.1 ; 15.6)$ & & $11.6(10.9 ; 12.3)$ & \\
\hline Yes & $34,522(61.2)$ & $14.9(14.3 ; 15.6)$ & & $12.1(11.5 ; 12.6)$ & \\
\hline Leisure-time physical activity ** & & & $<0.001$ & & $<0.001$ \\
\hline Insufficiently active & $48,443(80.5)$ & $15.7(15.1 ; 16.2)$ & & $12.8(12.3 ; 13.3)$ & \\
\hline Sufficiently active & $11,212(19.5)$ & $11.8(10.8 ; 12.9)$ & & $8.1(7.3 ; 8.9)$ & \\
\hline Smokes & & & $<0.001$ & & $<0.001$ \\
\hline No & $51,473(85.3)$ & $14.1(13.6 ; 14.7)$ & & $11.4(11.0 ; 11.9)$ & \\
\hline Yes & $8,729(14.7)$ & $19.4(17.9 ; 20.9)$ & & $14.5(13.2 ; 15.8)$ & \\
\hline Alcohol & & & 0.003 & & $<0.001$ \\
\hline Less than once a week & $46,976(76.0)$ & $15.3(14.8 ; 15.9)$ & & $12.4(11.9 ; 12.9)$ & \\
\hline At least once a week & $13,226(24.0)$ & $13.6(12.6 ; 14.5)$ & & $10.4(9.5 ; 11.3)$ & \\
\hline Health problems & & & $<0.001 *$ & & $<0.001$ * \\
\hline None & $27,388(44.6)$ & $8.1(7.5 ; 8.6)$ & & $6.6(6.1 ; 7.1)$ & \\
\hline 1 & $16,196(26.5)$ & $14.0(13.1 ; 15.0)$ & & $10.8(10.0 ; 11.6)$ & \\
\hline 2 & $8,406(14.4)$ & $21.0(19.4 ; 22.5)$ & & $15.7(14.4 ; 17.0)$ & \\
\hline 3 or more & $8,212(14.5)$ & $31.7(30.0 ; 33.4)$ & & $26.3(24.7 ; 27.9)$ & \\
\hline Total & - & $14.9(14.4 ; 15.4)$ & & $11.9(11.4 ; 12.3)$ & \\
\hline
\end{tabular}

* p-value for linear trend;

** Lost information for skin color $(n=273)$ and leisure-time physical activity $(n=547)$. 
Table 2

Crude and adjusted prevalence ratios (PR) for sleep disturbances and daytime fatigue among Brazilian adults ( $N=60,202)$.

\begin{tabular}{|c|c|c|c|c|c|c|c|c|}
\hline & \multicolumn{4}{|c|}{ Sleep problems } & \multicolumn{4}{|c|}{ Daytime fatigue } \\
\hline & \multicolumn{2}{|l|}{ Crude } & \multicolumn{2}{|c|}{ Adjusted } & \multicolumn{2}{|l|}{ Crude } & \multicolumn{2}{|c|}{ Adjusted } \\
\hline & PR $(95 \% \mathrm{Cl})$ & p-value & PR $(95 \% \mathrm{Cl})$ & p-value & PR $(95 \% \mathrm{Cl})$ & $p$-value & PR $(95 \% \mathrm{Cl})$ & p-value \\
\hline Sex & & $<0.001$ & & $<0.001$ & & $<0.001$ & & $<0.001$ \\
\hline Male & 1.00 & & 1.00 & & 1.00 & & 1.00 & \\
\hline Female & $1.62(1.51 ; 1.74)$ & & $1.60(1.49 ; 1.72)$ & & $1.76(1.62 ; 1.91)$ & & $1.75(1.61 ; 1.90)$ & \\
\hline Age (years) & & $<0.001$ & & $<0.001$ & & $<0.001$ & & $<0.001$ \\
\hline $18-29$ & 1.00 & & 1.00 & & 1.00 & & 1.00 & \\
\hline $30-39$ & $1.21(1.09 ; 1.35)$ & & $1.20(1.08 ; 1.34)$ & & $1.20(1.07 ; 1.34)$ & & $1.18(1.06 ; 1.32)$ & \\
\hline $40-49$ & $1.53(1.37 ; 1.71)$ & & $1.50(1.35 ; 1.68)$ & & $1.31(1.17 ; 1.48)$ & & $1.29(1.14 ; 1.45)$ & \\
\hline $50-59$ & $1.88(1.69 ; 2.10)$ & & $1.87(1.67 ; 2.08)$ & & $1.33(1.18 ; 1.50)$ & & $1.32(1.17 ; 1.49)$ & \\
\hline 60 or more & $1.87(1.68 ; 2.07)$ & & $1.82(1.64 ; 2.02)$ & & $1.19(1.06 ; 1.34)$ & & $1.15(1.02 ; 1.30)$ & \\
\hline Skin color & & 0.280 & & & & 0.682 & & \\
\hline White & 1.00 & & - & & 1.00 & & - & \\
\hline Black & $0.93(0.83 ; 1.04)$ & & - & & $0.94(0.82 ; 1.07)$ & & - & \\
\hline Brown & $1.04(0.97 ; 1.12)$ & & - & & $0.98(0.91 ; 1.06)$ & & - & \\
\hline Asian/Native South American & $0.98(0.73 ; 1.33)$ & & - & & $1.10(0.84 ; 1.45)$ & & - & \\
\hline Education & & $<0.001$ & & $<0.001$ * & & $<0.001$ & & $<0.001$ * \\
\hline None & 1.00 & & 1.00 & & 1.00 & & 1.00 & \\
\hline Incomplete primary level & $0.89(0.81 ; 0.98)$ & & $0.93(0.85 ; 1.02)$ & & $0.98(0.87 ; 1.09)$ & & $0.97(0.87 ; 1.09)$ & \\
\hline Complete primary level & $0.73(0.65 ; 0.82)$ & & $0.87(0.77 ; 0.98)$ & & $0.82(0.72 ; 0.94)$ & & $0.85(0.74 ; 0.97)$ & \\
\hline Secondary level & $0.62(0.56 ; 0.69)$ & & $0.75(0.67 ; 0.82)$ & & $0.79(0.70 ; 0.88)$ & & $0.79(0.70 ; 0.89)$ & \\
\hline Higher education & $0.67(0.59 ; 0.76)$ & & $0.73(0.64 ; 0.83)$ & & $0.83(0.72 ; 0.96)$ & & $0.79(0.69 ; 0.92)$ & \\
\hline Wealth index (quintiles) & & $<0.001$ * & & 0.451 & & 0.090 & & \\
\hline 1st (richer) & 1.00 & & 1.00 & & 1.00 & & - & \\
\hline $2^{\text {nd }}$ & $0.95(0.86 ; 1.05)$ & & $0.98(0.88 ; 1.08)$ & & $1.03(0.92 ; 1.16)$ & & - & \\
\hline 3 rd & $0.97(0.87 ; 1.07)$ & & $1.03(0.93 ; 1.14)$ & & $1.13(1.01 ; 1.27)$ & & - & \\
\hline $4^{\text {th }}$ & $0.91(0.82 ; 1.00)$ & & $0.99(0.89 ; 1.09)$ & & $1.04(0.93 ; 1.17)$ & & - & \\
\hline $5^{\text {th }}$ (poorer) & $0.82(0.74 ; 0.91)$ & & $0.93(0.83 ; 1.04)$ & & $0.96(0.86 ; 1.09)$ & & - & \\
\hline Lives with a partner & & 0.939 & & & & 0.294 & & \\
\hline No & 1.00 & & - & & 1.00 & & - & \\
\hline Yes & $1.00(0.94 ; 1.07)$ & & - & & $1.04(0.97 ; 1.12)$ & & - & \\
\hline Leisure-time physical activity & & $<0.001$ & & 0.002 & & $<0.001$ & & $<0.001$ \\
\hline Insufficiently active & 1.00 & & 1.00 & & 1.00 & & 1.00 & \\
\hline Sufficiently active & $0.76(0.69 ; 0.83)$ & & $0.86(0.77 ; 0.95)$ & & $0.63(0.57 ; 0.71)$ & & $0.69(0.62 ; 0.77)$ & \\
\hline Smokes & & $<0.001$ & & $<0.001$ & & $<0.001$ & & $<0.001$ \\
\hline No & 1.00 & & 1.00 & & 1.00 & & 1.00 & \\
\hline Yes & $1.38(1.26 ; 1.50)$ & & $1.38(1.27 ; 1.50)$ & & $1.27(1.15 ; 1.40)$ & & $1.34(1.22 ; 1.48)$ & \\
\hline Alcohol & & 0.003 & & 0.048 & & $<0.001$ & & 0.833 \\
\hline Less than once a week & 1.00 & & 1.00 & & 1.00 & & 1.00 & \\
\hline At least once a week & $0.88(0.81 ; 0.96)$ & & $1.09(1.00 ; 1.19)$ & & $0.84(0.76 ; 0.92)$ & & $0.99(0.89 ; 1.09)$ & \\
\hline Health problems & & $<0.001$ & & $<0.001$ & & $<0.001$ & & $<0.001$ \\
\hline None & 1.00 & & 1.00 & & 1.00 & & 1.00 & \\
\hline 1 & $1.73(1.57 ; 1.90)$ & & $1.67(1.52 ; 1.84)$ & & $1.62(1.46 ; 1.81)$ & & $1.67(1.50 ; 1.87)$ & \\
\hline 2 & $2.60(2.35 ; 2.87)$ & & $2.46(2.21 ; 2.74)$ & & $2.36(2.11 ; 2.65)$ & & $2.64(2.34 ; 2.98)$ & \\
\hline 3 or more & $3.93(3.60 ; 4.28)$ & & $3.64(3.30 ; 4.03)$ & & $3.96(3.60 ; 4.36)$ & & $4.69(4.20 ; 5.24)$ & \\
\hline
\end{tabular}

Note: 1st level: sex, age and skin color; 2nd level: education, wealth index and lives with a partner; 3rd level: leisure-time physical activity, smokes and alcohol intake.

* $\mathrm{p}$-value for linear trend. 


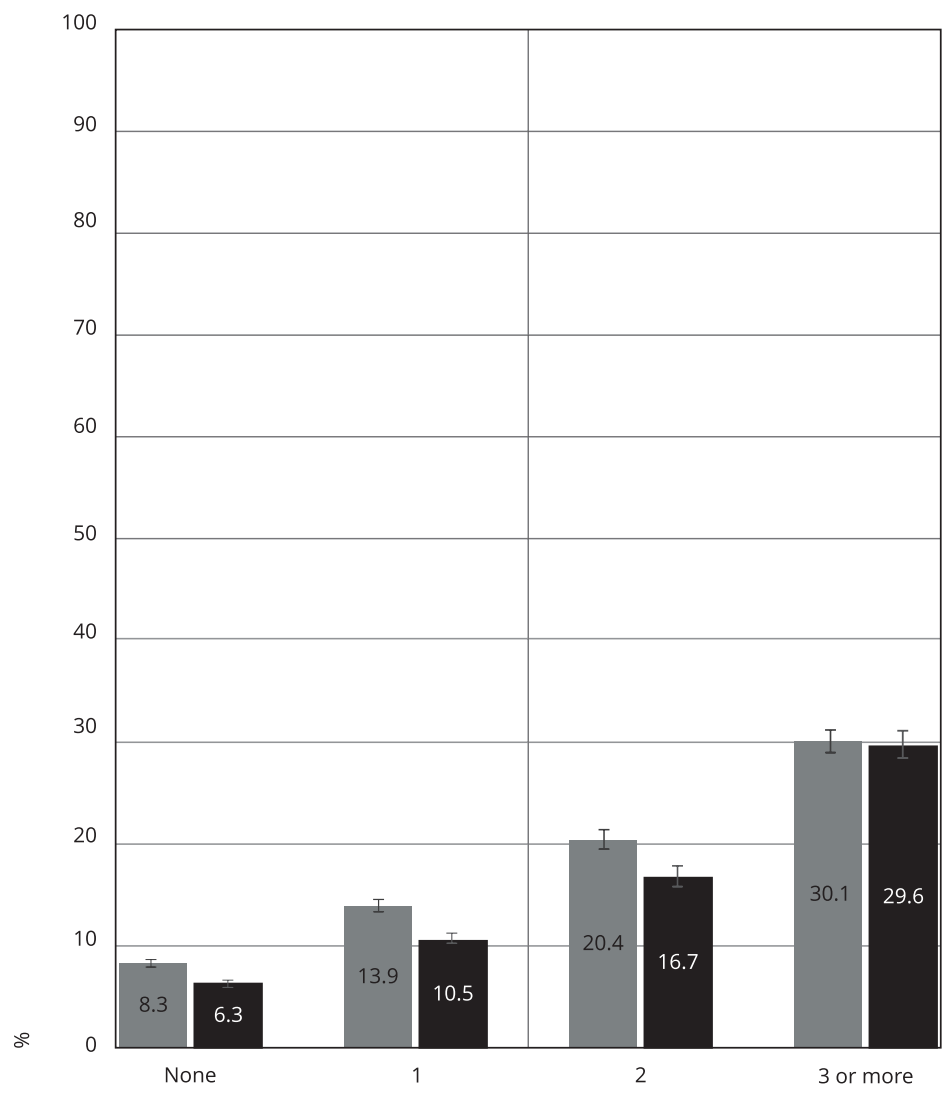

Sleep disturbance

Daytime fatigue

Chronic health conditions

\section{Discussion}

This study showed that about $15 \%$ and $12 \%$ of the Brazilian adult population reported sleep disturbances and daytime fatigue, respectively. These outcomes were more frequent in women, individuals aged 50-59 years, with no formal education, sedentary and current smokers. The frequency of simultaneous occurrence of sleep disturbances and daytime fatigue decreased as the education level increased and increased as the number of health problems increased.

Prevalence ratios of variables associated to sleep disturbances and daytime fatigue were in the same direction. As in other studies, higher prevalence of sleep disturbances and daytime fatigue were found in women 6,20,22,24,25,26. A meta-analysis identified a $40 \%$ higher risk of insomnia for women, regardless of the criteria used to define the outcome 24 . Some factors over the reproductive life of women such as the menstrual cycle, pregnancy and menopause may explain, at least partially, the negative impacts caused by these conditions on their sleep 25. During pregnancy, changes in hormonal secretion occur, especially for cortisol, contributing to difficulties in falling asleep. During the menopause period, hot flashes as result of estrogen fluctuation may also disturb sleep 25. Depression and anxiety are also important determinants of sleep and are more prevalent in women, further contributing for the difference that was observed for sex 25 . In addition, women search for health services more often than men; thus, resulting in a higher probability of being diagnosed with sleep disturbances when compared to men 25. Thus, sex differences in sleep disturbances may be both biological and social. 
2a) Sleep disturbances

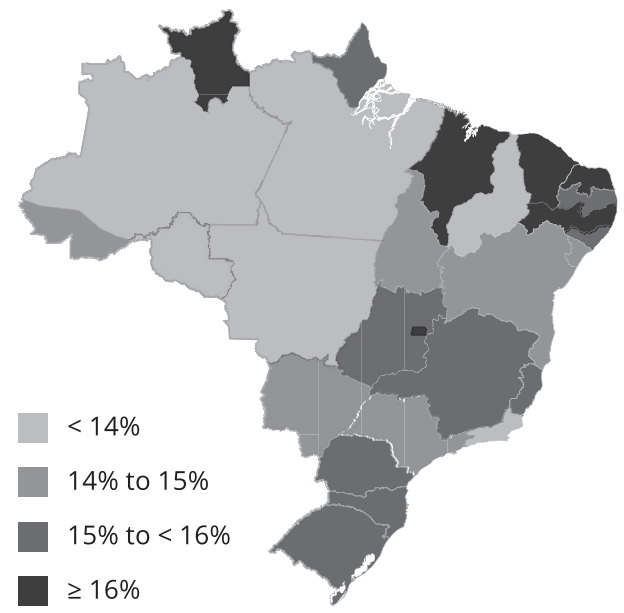

2b) Daytime fatigue

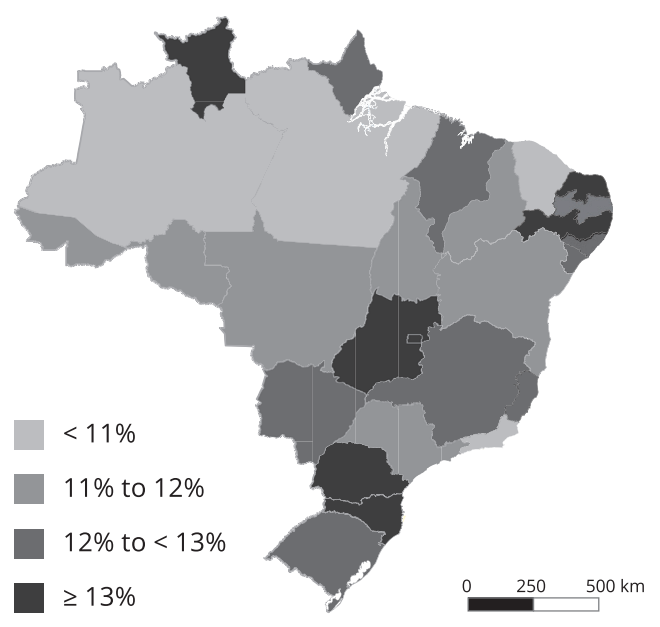

The aging process can naturally impair the sleep quality due to physiological changes such as a mismatch in the biological clock, which leads older individuals to wake up earlier, sleep later and decrease sleep duration 27. In addition, health conditions in older adults may have a higher impact in sleep health and consequently, in daytime fatigue 27 . Although several studies have found a higher risk of sleep disturbances and fatigue/sleepiness in older individuals 6,12,26, this study found little reduction in PR for this age group when compared to the 50-59 years group. This result may suggest the presence of survivorship bias that can be observed in cross-sectional studies when evaluating older age groups from underdeveloped settings 28 .

Sleep disturbances and daytime fatigue were higher among Brazilian adults with lower education level. Similar to this result, a study on insomnia prevalence in Greece found that individuals with lower education presented prevalence of insomnia 92\% higher when compared to the group with higher education level 26. These results may be explained due to higher schooling being associated to higher income and access to information and health services 26,29 . Thus, individuals with higher education levels may be more aware of the importance of sleep and of the conditions to increase its quality. Furthermore, unemployment and adverse socioeconomic conditions are strongly associated to insomnia 30 .

Regarding health behaviors, this study found that physically active individuals and non-smokers presented lower prevalence for both outcomes. These results corroborate other studies 5,12,17,26,31. Physical activity can have an important role in circadian rhythm regulation, tissue restoration and other functions that contribute to improve night sleep and rest 32 . On the other hand, smoking may be harmful for sleep health due to its stimulant effect, in addition to increasing the risk of breathing disorders 31 .

The association between sleep and health problems is consolidated in the literature 4,5,6,7,10,17. Mellinger et al. 33 observed that individuals with two or more health problems presented a higher risk of sleep disorders. Similarly, Luo et al. 6 found that a higher number of chronic diseases was associated to a higher risk of insomnia, suggesting that there is a synergic effect among health problems, which leads to a worse general health and sleep health.

Differences of sleep disturbances and daytime fatigue according to Federation Units were found. Brazil is a continental-size country and some of its regions and Federation Units are located near 
the Equator Line with similar day and night periods around 12 hours. Other regions like the South, present higher daylight periods in the Summer and the opposite occurs during the Winter. Changes according to seasons may affect sleep outcomes as sleep duration and schedule sleep regulation 34 . Another explanation is that in Brazil, the daylight-saving time during Summer is only adopted in some regions (South, Southeast and Central). Studies have shown that removing one hour in daylight time may be harmful to sleep 35,36 .

This study presents strengths and limitations. Among the strengths, this is a population-based nationwide representative study on sleep disturbances and daytime fatigue in Brazil, including over 60,000 adult participants and evaluating sociodemographic, behavioral and health conditions variables. Additionally, the findings of this study add consistency to the association between sleep disturbances and female sex, low education levels, older age, lack of physical activity, smoking, and chronic morbidity, as reported by other studies 5,6,12,15,17,22.

Among the limitations, the question used to ascertain the presence of sleep disturbances includes several sleep disturbances and does not allow the separation between long sleep latency from nocturnal awakenings or long nocturnal sleep duration. Furthermore, this question probably covers sleep disturbances with different association patterns. For example, literature shows problems related to short sleep such as difficulty in falling asleep and frequently waking up during the night as common associated factors; however, these are not necessarily the same factors associated to extended sleep time or sleeping more than usual. This limitation does not allow a separate analysis on disturbances and this may impair comparability with the available literature $14,16,18,19$. Another limitation is the reverse causality in associations between behavioral factors and health problems, since it was a cross-sectional study the temporality could not be defined. Furthermore, lack of physical activity, smoking and sleep disturbances may impair physical and mental health independently from the causal relationship between them. Finally, the possibility of interviewer bias exists, but it is important to highlight that the NHS trained their workers to apply the questionnaire. Sleep disturbances and daytime fatigue, as perceived by individuals, affect a considerable portion of the Brazilian population, thus representing a critical public health issue. Strategies to decrease the prevalence of the outcomes should be encouraged and focused on the modifiable factors for the following risk groups: women, older individuals, with lower education level, physically inactive, smokers, and with higher number of chronic health problems.

\section{Contributors}

A. Wendt, C. S. Costa, A. K. F. Machado, F. S. Costa, R. G. Neves, T. R. Flores, I. Santos and F. C. Wehrmeister participated in the critical and intellectual review of the results, data analysis and interpretation, and approved the final version of this manuscript ensuring the relevant ethical procedures.

\section{Additional informations}

ORCID: Andrea Wendt (0000-0002-4640-2254); Caroline Santos Costa (0000-0002-3522-1546); Adriana Kramer Fiala Machado (0000-0002-68001064); Francine Santos Costa (0000-0001-9558937X); Rosália Garcia Neves (0000-0001-67989130); Thaynã Ramos Flores (0000-0003-00981681); Iná Santos (0000-0003-1258-9249); Fernando César Wehrmeister (0000-0001-7137-1747).

\section{Acknowledgments}

We would like to thank the Graduate Studies Coordinating Board (Capes) and Brazilian National Research Council (CNPq). A. Wendt, C. S. Costa, F. S. Costa, R. G. Neves and T. R. Flores are funded by the Capes PhD scholarship, and A. K. F. Machado is funded by a CNPq PhD scholarship. 


\section{References}

1. Bryant PA, Trinder J, Curtis N. Sick and tired: does sleep have a vital role in the immune system? Nat Rev Immunol 2004; 4:457-67.

2. Copinschi G, Leproult R, Spiegel K. The important role of sleep in metabolism. Front Horm Res 2014; 42:59-72.

3. Mukherjee S, Patel SR, Kales SN, Ayas NT, Strohl KP, Gozal D, et al. An Official American Thoracic Society Statement: the importance of healthy sleep. Recommendations and future priorities. Am J Respir Crit Care Med 2015; 191:1450-8

4. Cappuccio FP, D’Elia L, Strazzullo P, Miller MA. Sleep duration and all-cause mortality: a systematic review and meta-analysis of prospective studies. Sleep 2010; 33:585-92.

5. Foley D, Ancoli-Israel S, Britz P, Walsh J. Sleep disturbances and chronic disease in older adults: results of the 2003 National Sleep Foundation Sleep in America Survey. J Psychosom Res 2004; 56:497-502.

6. Luo J, Zhu G, Zhao Q, Guo Q, Meng H, Hong $Z$, et al. Prevalence and risk factors of poor sleep quality among Chinese elderly in an urban community: results from the Shanghai Aging Study. PLoS One 2013; 8:e81261.

7. Taheri S. The link between short sleep duration and obesity: we should recommend more sleep to prevent obesity. Arch Dis Child 2006; 91:881-4.

8. Alhola P, Polo-Kantola P. Sleep deprivation: impact on cognitive performance. Neuropsychiatr Dis Treat 2007; 3:553-67.

9. Mirghani HO, Mohammed OS, Almurtadha YM, Ahmed MS. Good sleep quality is associated with better academic performance among Sudanese medical students. BMC Res Notes 2015; 8:706.

10. Hyyppa MT, Kronholm E. Quality of sleep and chronic illnesses. J Clin Epidemiol 1989; 42:633-8

11. Dinges DF. An overview of sleepiness and accidents. J Sleep Res 1995; 4:4-14.

12. Krueger PM, Friedman EM. Sleep duration in the United States: a cross-sectional population-based study. Am J Epidemiol 2009; 169:1052-63.

13. Jiang X, Hardy LL, Baur LA, Ding D, Wang L, Shi H. Sleep duration, schedule and quality among urban Chinese children and adolescents: associations with routine after-school activities. PLoS One 2015; 10:e0115326.

14. Polo-Kantola P, Laine A, Aromaa M, Rautava P, Markkula J, Vahlberg T, et al. A populationbased survey of sleep disturbances in middleaged women: associations with health, health related quality of life and health behavior. Maturitas 2014; 77:255-62.
15. Stranges S, Tigbe W, Gomez-Olive FX, Thorogood M, Kandala NB. Sleep problems: an emerging global epidemic? Findings from the INDEPTH WHO-SAGE study among more than 40,000 older adults from 8 countries across Africa and Asia. Sleep 2012; 35:117381.

16. Ruiz AJ, Sepúlveda MA, Martínez PH, Muñoz MC, Mendoza LO, Centanaro OP, et al. Prevalence of sleep complaints in Colombia at different altitudes. Sleep Sci 2016; 9:100-5.

17. Hoefelmann LP, Lopes ADS, Silva KSD, Silva SGD, Cabral LGA, Nahas MV. Lifestyle, selfreported morbidities, and poor sleep quality among Brazilian workers. Sleep Med 2012; 13:1198-201.

18. Santos-Silva R, Bittencourt LR, Pires ML, de Mello MT, Taddei JA, Benedito-Silva AA, et al. Increasing trends of sleep complaints in the city of Sao Paulo, Brazil. Sleep Med 2010; 11:520-4.

19. Rocha FL, Uchoa E, Guerra HL, Firmo JO, Vidigal PG, Lima-Costa MF. Prevalence of sleep complaints and associated factors in community-dwelling older people in Brazil: the Bambui Health and Ageing Study (BHAS). Sleep Med 2002; 3:231-8.

20. Nunes MA, Pinheiro AP, Bessel M, Brunoni AR, Kemp AH, Benseñor IM, et al. Common mental disorders and sociodemographic characteristics: baseline findings of the Brazilian Longitudinal Study of Adult Health (ELSABrasil). Rev Bras Psiquiatr 2016; 38:91-7.

21. Beijamini F, Knutson KL, Lorenzi-Filho G, Egan KJ, Taporoski TP, De Paula LK, et al. Timing and quality of sleep in a rural Brazilian family-based cohort, the Baependi Heart Study. Sci Rep 2016; 6:39283.

22. Bittencourt LR, Santos-Silva R, Taddei JA, Andersen ML, de Mello MT, Tufik S. Sleep complaints in the adult Brazilian population: a national survey based on screening questions. J Clin Sleep Med 2009; 5:459-63.

23. Instituto Brasileiro de Geografia e Estatística. PNS (Pesquisa Nacional de Saúde): percepção do estado de saúde, estilos de vida e doenças crônicas. Rio de Janeiro: Instituto Brasileiro de Geografia e Estatística; 2013.

24. Zhang B, Wing YK. Sex differences in insomnia: a meta-analysis. Sleep 2006; 29:85-93.

25. Collop NA, Adkins D, Phillips BA. Gender differences in sleep and sleep-disordered breathing. Clin Chest Med 2004; 25:257-68.

26. Paparrigopoulos T, Tzavara C, Theleritis C, Psarros C, Soldatos C, Tountas Y. Insomnia and its correlates in a representative sample of the Greek population. BMC Public Health 2010; 10:531. 
27. Phillips B, Ancoli-Israel S. Sleep disorders in the elderly. Sleep Med 2001; 2:99-114.

28. Kraemer HC, Yesavage JA, Taylor JL, Kupfer D. How can we learn about developmental processes from cross-sectional studies, or can we? Am J Psychiatry 2000; 157:163-71.

29. Yoon HS, Yang JJ, Song M, Lee HW, Han S, Lee SA, et al. Correlates of self-reported sleep duration in middle-aged and elderly Koreans: From the Health Examinees Study. PLoS One 2015; 10:e0123510.

30. Hirotsu C, Bittencourt L, Garbuio S, Andersen ML, Tufik S. Sleep complaints in the Brazilian population: Impact of socioeconomic factors. Sleep Sci 2014; 7:135-42.

31. Davila EP, Lee DJ, Fleming LE, LeBlanc WG, Arheart K, Dietz N, et al. Sleep disorders and secondhand smoke exposure in the U.S. population. Nicotine Tob Res 2010; 12:294-9.
32. Driver HS, Taylor SR. Exercise and sleep. Sleep Med Rev 2000; 4:387-402.

33. Mellinger GD, Balter MB, Uhlenhuth EH. Insomnia and its treatment. Prevalence and correlates. Arch Gen Psychiatry 1985; 42:225-32.

34. Randler C, Rahafar A. Latitude affects morningness-eveningness: evidence for the environment hypothesis based on a systematic review. Sci Rep 2017; 7:39976.

35. Barnes CM, Drake CL. Prioritizing sleep health: public health policy recommendations. Perspect Psychol Sci 2015; 10:733-7.

36. Medina D, Ebben M, Milrad S, Atkinson B, Krieger AC. Adverse effects of daylight saving time on adolescents' sleep and vigilance. J Clin Sleep Med 2015; 11:879-84. 


\section{Resumo}

O objetivo deste estudo foi descrever a prevalência de distúrbios de sono e fadiga durante o dia e sua associação com fatores sociodemográficos e comportamentais. Dados da Pesquisa Nacional de Saúde realizada no Brasil em 2013 com 60.202 adultos ( $\geq 18$ anos) foram usados. Os desfechos avaliados foram relatos de distúrbios de sono $e$ fadiga durante o dia nas últimas duas semanas. Distúrbios do sono foram definidos como a presença de dificuldade em cair no sono, acordar com frequência durante a noite ou dormir mais do que o usual e a fadiga durante o dia foi definida como presença de não se sentir descansado e motivado durante o dia, se sentir cansado e falta de energia. Aspectos sociodemográficos, de estilo de vida e aspectos crônicos de saúde foram explorados como exposições para ambos os desfechos. As prevalências de distúrbios de sono e fadiga durante o dia foram 14,9\% $(14,4-15,4)$ e 11,9\% $(11,4-12,3)$, respectivamente. Ambos os desfechos foram mais comuns em mulheres, idosos, pessoas sem educação formal, fumantes e pessoas que não praticam atividade física. A associação com educação foi reversa (quanto maior a escolaridade, menor a razão de prevalência - RP - de distúrbios de sono e fadiga durante o dia; valor de p ajustado para tendência $<0,001)$. A prevalência de distúrbios de sono simultaneamente combinados com fadiga durante 0 dia foi de $6,7 \%(6,4-7,1)$ e foi em torno de seis vezes maior para os que tinham três ou mais distúrbios crônicos de saúde (RP = 6,2; IC95\%: 5,3-7,2). Deve-se encorajar estratégias para reduzir a prevalência de distúrbios de sono e fadiga durante o dia direcionadas a indivíduos com doenças crônicas que compartilham outros fatores de risco modificáveis.

Distúrbios do Sono; Fadiga; Estudos Transversais; Inquéritos Epidemiológicos

\section{Resumen}

El objetivo de este estudio fue describir la prevalencia de los trastornos de sueño y fatiga diurna, y su relación con factores sociodemográficos $y$ de comportamiento. Se manejaron datos de la Encuesta Nacional de Salud que se llevó a cabo en Brazil en 2013 con 60.202 adultos ( $\geq 18$ años de edad). En los resultados evaluados se autoinformaron trastornos del sueño y fatiga diurna al menos durante dos semanas. El trastorno del sueño se definió como presencia o dificultad en quedarse dormido, despertarse frecuentemente durante la noche o dormir más de lo normal y sufrir fatiga diurna, así como la sensación de no haber descansado y estar inactivo de día, sintiéndose cansado y falto de energía. Se investigaron aspectos sociodemográficos, estilo de vida y dolencias crónicas como la exposición a ambos resultados. La prevalencia de trastornos de sueño y fatiga diurna fueron 14,9\% $(14,4-15,4)$ y 11,9\% $(11,4-12,3)$, respectivamente. Ambos resultados fueron más comunes en mujeres, personas con edad avanzada, sin educación formal, fumadores e individuos físicamente inactivos. La asociación con la educación fue inversa (cuanto más alto era el nivel de educación, más bajo era la $P R$ de trastornos del sueño y fatiga diurna; valor de $p$ ajustado para tendencia $<0,001)$. La prevalencia de trastornos del sueño, combinada concomitantemente con la fatiga diurna, fue 6,7\% (6,4$7,1)$ y casi 6 veces superior entre quienes sufrían tres o más trastornos crónicos de salud $(P R=6,2$; 95\%CI: 5,3-7,2). Las estrategias para disminuir la prevalencia de los trastornos del sueño y fatiga diurna deberían estar promovidas y centradas en personas enfermas crónicamente que compartan otros factores de riesgo modificables.

Trastornos del Sueño; Fatiga; Estudios

Transversales; Encuestas Epidemiológicas
Submitted on 03/May/2018

Final version resubmitted on 19/Sep/2018

Approved on 01/Oct/2018 